\title{
HUBUNGAN DUKUNGAN KELUARGA DENGAN KEJADIAN DEPRESI PADA PASIEN KANKER PAYUDARA DI RUMAH SAKIT UMUM DAERAH RADEN MATTAHER JAMBI
}

\author{
Desti Herlianda Siregar ${ }^{1}$, Nurfitriani ${ }^{2}$ ) \\ ${ }^{1)}$ Program Studi Ilmu Keperawatan STIKes Baiturrahim Jambi \\ 2) Program Studi DIII Keperawatan STIKes Baiturrahim Jambi \\ Email :Destisiregar20@gmail.com
}

\begin{abstract}
Cancer is a group of diseases caused by single cells that grow abnormally and uncontrollably. Cancer which is the number two cause of death in the world in 2012 was breast cancer (12.90\%) after lung cancer (19.70\%).In Indonesia, the incidence of breast cancer is highest in the province of Yogyakarta at 40 per 100.000 populations.Jambi province ranks $13^{\text {th }}$ highest out of 34 provinces, with cancer incidence of 1.5 per 1000 population.From 2014 to 2017 there were 1,287 breast cancer patients and had received treatment. Raden Mattaher hospital Jambi is one of the places that served breast cancer treatment, in January to April 2018; there were 39 cases of breast cancer in poly surgery. This study aimed to determine the correlation between family supports with the incidence of depression in breast cancer patients at Raden Mattaher hospital Jambi. This is an analytic descriptive research with population were 39 breast cancer women, it used total sampling technique. This study was conducted at Raden Mattaher hospital Jambi toward 34 breast cancer patients. While 5 patients were respondents in the initial survey. The instruments used a demographic data questionnaire, family support, the incidence of depression; it used univariate and bivariate analysis (fisher exact test). The findings indicated that there is no significant correlation between family supports with the incidence of depression in breast cancer patients with $p$ score were $p=0.769$. It is concluded that the correlation of good family support did not effect in patients to depression. It is suggested to the next research can study about the correlation of family support with the incidence of depression in breast cancer patients with different method such as qualitative.
\end{abstract}

Keywords: Breast Cancer, Depression, Family Support

\begin{abstract}
ABSTRAK
Kanker merupakan sekelompok penyakit yang disebabkan oleh sel tunggal yang tumbuh secara tidak normal dan tidak terkendali. Kanker yang menjadi penyebab kematian nomor dua di dunia pada tahun 2012 adalah kanker payudara (12,90\%) setelah kanker paru-paru $(19,70 \%)$. Di Indonesia, kejadian kanker payudara tertinggi di provinsi Yogyakarta yaitu 40 per 100.000 penduduk. Provinsi Jambi menempati urutan ke 13 dari 34 provinsi, dengan insiden kanker 1,5 per 1.000 penduduk. Dari 2014 hingga 2017 ada sebanyak 1.287 pasien kanker payudara yang telah mendapatkan perawatan. Rumah Sakit Raden Mattaher Jambi salah satu tempat yang melayani perawatan kanker payudara, pada Januari hingga April 2018; terdapat 39 kasus kanker payudara di Poli Bedah Rawat Jalan. Penelitian ini bertujuan mengetahui hubungan antara dukungan keluarga dengan kejadian depresi pada pasien kanker payudara di Rumah Sakit Raden Mattaher Jambi. Penelitian ini merupakan penelitian deskriptif analitik dengan populasi sebanyak 39 wanita penderita kanker payudara, menggunakan teknik total sampling. Penelitian ini dilakukan di rumah sakit Raden Mattaher Jambi terhadap 34 pasien kanker payudara. Sedangkan 5 pasien telah menjadi responden dalam survei awal. Instrumen pada
\end{abstract}


penelitian ini menggunakan kuesioner data demografi, dukungan keluarga, kejadian depresi; menggunakan analisis univariat dan bivariat (uji fisher exact). Hasil penelitian menunjukkan bahwa tidak ada hubungan yang bermakna antara dukungan keluarga dengan kejadian depresi pada pasien kanker payudara dengan nilai $p$ value $=0,769$ atau $p$ $>0,005$. Disimpulkan bahwa hubungan dukungan keluarga yang baik tidak mempengaruhi pasien untuk mengalami depresi. Disarankan agar peneliti selanjutnya dapat meneliti lebih lanjut tentang hubungan dukungan keluarga dengan kejadian depresi pada pasien kanker payudara dengan metode berbeda seperti kualitatif.

Kata Kunci: Dukungan Keluarga, Depresi, Kanker Payudara

\section{PENDAHULUAN}

Kanker merupakan suatu golongan penyakit yang ditimbulkan oleh sel tunggal yang tumbuh abnormal dan tidak terkendali, sehingga dapat menjadi tumor ganas yang dapat menghancurkan dan merusak sel atau jaringan sehat. Kanker merupakan suatu kondisi dimana sel telah kehilangan pengendalian dan mekanisme normal sehingga mengalami pertumbuhan dan perkembangbiakan, sel-sel kanker membentuk suatu masa dari jaringan ganas yang masuk ke jaringan di sekitarnya (invasif) dan bisa menyebar atau metastasis keseluruh tubuh (Mulyani, 2013). Menurut WHO (2013) dalam Kemenkes (2014), di seluruh dunia kanker merupakan masalah kesehatan yang terus bertambah jumlah penderitanya dan diperkirakan terdapat 14,1 juta kasus kanker baru yang terdiagnosa dan 8,2 juta kematian akibat kanker pada tahun 2012. Hal ini menjadi penyebab bertambahnya beban ekonomi negara dalam mengatasi masalah kesehatan penduduknya akibat kanker. Berbagai penyebab meningkatnya jumlah penderita kanker dapat diakibatkan oleh meningkatnya populasi manusia usia lanjut, meningkatnya konsumsi rokok dan alcohol, meningkatnya kebiasaan masyarakat melakukan diet tidak sehat, tidak membiasakan diri berolahraga, dan bahaya pencemaran lingkungan akibat perbuatan manusia yang tidak bertanggung jawab.

Kanker menjadi penyebab kematian nomor 2 di dunia sebesar $13 \%$ setelah penyakit kardiovaskular. Diperkirakan pada tahun 2030 insidens kanker dapat mencapai 26 juta orang dan 17 juta diantara meninggal akibat kanker, terlebih untuk negara miskin dan berkembang kejadiannya akan lebih cepat. kanker yang menjadi penyebab kematian setiap tahunnya adalah kanker paru, kanker hati, kanker abdomen, kanker kolorektal, dan kanker payudara.

Berdasarkan Data Riset Kesehatan Dasar (Riskesdas) dalam Kemenkes RI tahun (2013), prevalensikanker di Indonesia adalah 1,4 penduduk, atau sekitar 347.792 orang. Prevalensi kanker tertinggi berada pada Provinsi Yogyakarta, yaitu sebesar 4,1 per 1000 penduduk.Insiden kanker tertinggi pada perempuan adalah kanker payudara sebesar 40 per 100.000 dan prevalensi kanker payudara tertinggi berada di Provinsi Yogyakarta. Provinsi Jambi menempati urutan ke 13 tertinggi dari 34 Provinsiyang ada di Indonesia, dengan insiden kanker sebanyak 1,5 per 1000 penduduk, 
yang terjadi pada semua tingkat usia. Sedangkan kasus kanker payudara di Provinsi Jambi yaitu pada tahun 2014 sebanyak 341, tahun 2015 sebanyak 240, tahun 2016 sebanyak 425, tahun 2017 sebanyak 281. Jadi total penderita kanker payudara sebanyak 1.287 dan sudah mendapatkan perawatan (Dinas Kesehatan Provinsi Jambi, 2017).

Data Rekam Medik rumah sakit Raden Mattaher Jambi tahun 2017 melaporkan terdapat 107 wanita mengalami kanker payudara yang dirawat inap di beberapa ruangan, dan di poli bedah rawat jalan terdapat 99 kasus kanker payudara. Pada Januari - April 2018 terdapat 39 kasus kanker payudara di poli rawat jalan, sedangkan Januari Mei 2018 terdapat 45 wanita dengan kanker payudara yang di rawat inap (Rekam Medik Rumah Sakit Raden Mattaher, 2018).

Kanker payudara merupakan penyakit yang dapat mempengaruhi setiap aspek kehidupan manusia dan dapat menimbulkan masalah-masalah fisiologi, psikologi, dan sosial. Reaksi psikologi yang dapat muncul setelah pasien didiagnosis kanker payudara pada umumnya merasa shock mental, takut, tidak bisa menerima kenyataan, sampai pada keadaan depresi (Andrews G,2010). Depresi merupakan bagian dari gangguan mood yang ditandai dengan hilangnya perasaan akan kendali diri dan pengalaman subjektif akan adanya penderitaan berat. Pasien depresi dapat disertai dengan beberapa gejala seperti kehilangan energi dan minat, merasa bersalah, sulit berkonsentrasi, hilang nafsu makan, dan muncul pikiran mengenai kematian atau ide bunuh diri. Dan tanda gejala lain dari gangguan depresi adalah penurunan tingkat aktivitas, kemampuan kognitif, pembicaraan, dan fungsi vegetatif seperti tidur, nafsu makan, aktivitas sosial, dan irama biologisnya (Hawari D, 2016).

Menurut PPDGJ III (Pedoman penggolongan dan diagnosis gangguan jiwa), tingkat depresi terdiri dari tiga bagian yaitu, depresi ringan, depresi sedang, dan depresi berat. Gejala dari depresi seperti perasaan murung, sedih, gairah hidup menurun, merasa bersalah, merasa berdosa, selalu ada penyesalan, menurunnya nafsu makan, menurunnya berat badan, konsentrasi dan daya ingat menurun, gangguan pola tidur, selalu merasa gelisah, hilangnya perasaan senang, libido menurun, selalu muncul pikiran tantang kematian (Hawari D, 2016).

Faktor resiko yang mempengaruhi terjadinya depresi pada pasien kanker diantaranya stadium lanjut, pengendalian nyeri, riwayat depresi, alkoholik, gangguan endokrin, gangguan neurologik, obat-obatan salah satunya Kemoterapi, sulit menerima atau menyesuaikan diri dengan diagnosa kanker, memiliki masalah alkohol dan narkoba, usia yang masih muda, tidak mendapat dukungan keluargamaupun dukungan sosial, tidak memiliki keyakinan terhadap keefektifan perawatan, perubahan fisik atau cacat fisik (Hawari D, 2016). Guna memperkuat mekanisme koping wanita penderi kanker payudara, ia harus diberi dorongan untuk mendapatkan dukungan. Pasangan, keluarga, dan temanteman dapat memberi bantuan praktik dan dukungan emosi 
meskipun ini hanya dapat diberikan dengan persetujuan dari wanita tersebut, karena tidak semua wanita ingin melibatkan keluarga dan teman-teman mereka (Andrews G,2010)

Dukungan keluarga merupakan faktor yang sangat penting bagi seseorang yang sedang menghadapi masalah dan dapat memotivasi orang tersebut dalam menjalani pengobatannya seperti pada pasien kanker payudara yang sedang menjalani kemoterapi, dukungan keluarga dapat berupa materi dan moril. Keluarga adalah teman terbaik bagi pasien kanker dalam menghadapi pertempuran dengan penyakitnya, dan dukungan keluarga terhadap pasien kanker sangat dibutuhkan guna mengangkat mental dan semangat hidup pasien (Mahwita,2012).

Berdasarkan survei awal yang dilakukan di Rumah Sakit Umum Daerah Raden Mattaher Jambi terhadap 5 orang pasien yang ratarata berusia diatas 35 tahun, 3 orang responden menyatakan bahwa mereka mendapat dukungan dari keluarga, keluarga selalu mendampingi selama perawatan, keluarga berperan aktif dalam setiap pengobatan, keluarga berusaha mencari kekurangan sarana dan peralatan perawatan, keluarga selalu mengingatkan dalam hal makan, dan obat. 3 orang responden tersebut juga menyatakan bahwa mereka menerima keadaan kondisi kesehatan mereka. tidak lagi merasa gagal, merasa berkecil hati, merasa sedih, merasa sedang dihukum, tidak ada pikiran untuk bunuh diri, namun nafsu makan tidak seperti biasanya, tidak dapat tidur dengan nyenyak seperti biasanya, lebih mudah lelah seperti biasanya. Selanjutnya, 2 orang responden menyatakan tidak dapat dukungan dari keluarga. Keluarga tidak seutuhnya mendampingi dalam perawatan, keluarga kurang memberikan pujian atau perhatian, keluarga tidak selalu berperan aktif dalam setiap pengobatan. Dan 2 orang responden juga menyatakan bahwa mereka ikhlas menerima kondisi kesehatan mereka walaupun terkadang masih merasa sedih, merasa gagal, merasa tidak percaya diri dihadapan org banyak, masih sering menangis, nafsu makan berkurang, lebih mudah lelah, tidur tidak nyenyak. Penelitian ini bertujuan mengetahui hubungan antara dukungan keluarga dengan kejadian depresi pada pasien kanker payudara di Rumah Sakit Umum Daerah Raden Mattaher Jambi.

\section{METODE PENELITIAN}

Penelitian ini merupakan penelitian kuantitatif dengan desain deskriptif analitik dengan pendekatancross sectional yang bertujuan untuk mengetahui hubungan antara dukungan keluarga dengan kejadian depresi pada pasien kanker payudara.Populasi dalam penelitian ini adalah pasienpasienkanker payudara di Rumah Sakit Umum Daerah Raden Mattaher Jambi, yang berjumlah 39 orang.Pengambilan sampel dalam penelitian ini sebanyak 34 responden dengan teknik total sampling. 5 orang responden sebelumnya telah dilakukansurvey awal. Penelitian ini telah dilaksanakan di Rumah Sakit Umum Daerah Raden Mattaher Jambi pada bulan September 2018. Hasil penelitian dianalisis secara 
univariat dan bivariat menggunakan

uji statistic fisher exact.

\section{HASIL DAN PEMBAHASAN}

A. Analisis Univariat

1. Karakteristik Responden Berdasarkan Umur

\begin{tabular}{lllll}
\hline Variabel & Minimum & Maximum & Mean & Std. Deviation \\
\hline Umur & 21 tahun & 63 tahun & 50,11 & 8,661 \\
\hline
\end{tabular}

Dari 34 orang pasien yang menjadi responden, yang mengalami kanker payudara rata-rata umur adalah 50,11 tahun, di usia termuda 21 tahun dan usia tertua 63 tahun dengan standar deviasi 8,661. Hasil penelitian ini sesuai dengan penelitian Mahwita (2012) tentang hubungan dukungan keluarga terhadap motivasi kanker payudara dalam menjalani kemoterapi diruang Cendrawasih I RSUD Arifin Achmad Provinsi Riau, menunjukkan bahwa 37 responden sebagian besar berusia 41-65 tahun sebanyak 27 responden $(73 \%)$. Responden yang berusia 20-40 tahun sebanyak 9 responden $(24,3 \%)$ dan responden yang berusia $>65$ tahun sebanyak 1 responden $(2,7 \%)$.

Reeder, Martin dan Koniak (2011) menjelaskan bahwa banyak wanita menderita kanker payudara setelah mereka berusia 35 tahun, dengan puncak kejadian pada usia antara 40 dan 60 tahun resiko individu meningkat seiring dengan pertambahan usia. Teori sebab akibat mencakup mekanisme hormonal yang melibatkan steroid endogen, agens virus, transmisi genetic, dan defisiensi imun.

\section{KarakteristikResponden Berdasarkan Pendidikan}

\begin{tabular}{cccc}
\hline \multirow{2}{*}{ No } & Kategori & \multicolumn{2}{c}{ Jumlah } \\
\cline { 3 - 4 } 1 & Dasar (SD/ SMP sederajat) & Nn & $\%$ \\
& & 88 & 223,52 \\
2 & Menengah (SMA sederajat) & 223 & 667,62 \\
3 & Tinggi (Diploma/ Sarjana) & 33 & 88,82 \\
& Total & 334 & 1100,00 \\
\hline
\end{tabular}

Dari 34 responden pada penelitian ini sebagian besar berpendidikan menengah (SMA sederajat) yaitu sebanyak 23 orang $(67,64 \%)$, Dasar (SD/ SMP sederajat) sebanyak 8 orang ( 23,52\%) dan Tinggi (Diploma/Sarjana) sebanyak 3 orang $(8,82 \%)$.
Penelitian ini sesuai dengan penelitian Riski (2015) tentang faktor-faktor yang mempengaruhi tingkat depresi pada pasien kanker payudara yang dirawat di RSUD Arifin Achmad Provinsi Riau, menunjukkan bahwa mayoritas responden memiliki tingkat 
pendidikan SMA sebanyak 23 responden $(38,3 \%)$, responden yang memiliki tingkat pendidikan SMP, $\mathrm{SD}$, dan perguruan tinggi masingmasing 19 responden $(31,7 \%), 17$ responden $(28,3 \%)$, dan 1 responden $(1,7 \%)$.

Menurut Mubarak, Khoirul, Nurul \& Supriadi (2003) dalam Riski
(2015) menjelaskan bahwa pendidikan seseorang akan mempengaruhi pola pikir kognitif, hal ini dipengaruhi oleh faktor informasi yang di dapatkan selama masa pendidikan dan pengalaman yang dialami seseorang.

3. Karakteristik Respondn Berdasarkan Pekerjaan

\begin{tabular}{clcc}
\hline \multirow{2}{*}{ No } & \multicolumn{1}{c}{ Kategori } & \multicolumn{2}{c}{ Jumlah } \\
\cline { 3 - 4 } & & $\mathrm{N}$ & $\%$ \\
\hline 1 & Tidak Bekerja (tidak bekerja, IRT) & 29 & 85,3 \\
2 & Bekerja (PNS,Wiraswasta,Pedagang,Petani) & 5 & 14,7 \\
& Total & 34 & 100,00
\end{tabular}

Dari 34 orang respondenyang kesehariannya tidak bekerja (tidak bekerja,IRT) sebanyak 29responden $(85,3 \%)$ dan yang bekerja (PNS,wiraswasta,petani,pedagang) sebanyak 5 responden $(14,7 \%)$.

Penelitian ini sesuai dengan penelitian Nurpeni dan Ratih (2012) tentang hubungan dukungan keluarga dengan tingkat kecemasan pada pasien kanker payudara di ruang Angsoka III RSUP Sanglah Denpasar, menunjukkan bahwa dari 60 responden yang memiliki pekerjaan sebanyak 30 responden (50\%), dan yang tidak bekerja atau menjadi IRT sebanyak 30 responden $(50 \%)$.

Menurut Widyastuti (2011) dalam Dewi (2014) menjelaskan bahwa status pekerjaan memberi dampak langsung pada dukungan keluarga, apabila penghasilan yang didapatkan kurang atau tidak ada, maka akan mempengaruhi dukungan Instrumen untuk menunjang pemberian dukungan untuk kesembuhan pasien.

\section{Karakteristik Responden Berdasarkan Status Perkawinan}

\begin{tabular}{clcc}
\hline \multirow{2}{*}{ No } & Kategori & \multicolumn{2}{c}{ Jumlah } \\
\cline { 3 - 4 } & & $\mathrm{N}$ & $\%$ \\
\hline 1 & Belum menikah & 1 & 3 \\
2 & Menikah dan punya pasangan & 33 & 97 \\
& Total & 34 & 10,00
\end{tabular}

Dari 34 orang yang menjadi responden, yang belum menikah sebanyak 1 responden (3\%) dan yang sudah menikah dan memiliki pasangan sebanyak 33 responden (97\%).
Penelitian ini sesuai dengan penelitian Riski (2015) tentang Faktor-faktor yang mempengaruhi tingkat depresi pada pasien kanker yang dirawat di RSUD Arifin Achmad Provinsi Riau, menunjukkan bahwa seluruh responden yang 
berjumlah 60 orang memiliki status perkawinan sudah menikah (100\%) Responden. Penelitian ini juga dilakukan oleh Widiyono (2017) tentang tingkat depresi pada pasien kanker di RSUP Dr. Sardjito, Yogyakarta, dan RSUP Prof. Dr. Margono Soekarjo, Purwokerto, yang menunjukkan bahwa dari 70 responden, jumlah responden yang tidak memiliki pasangan hidup atau janda lebih sedikit sebanyak 7 responden (10\%). Dan yang masih

\section{Gambaran Dukungan Keluarga Responden Kanker Payudara}

\begin{tabular}{clccc}
\hline \multirow{2}{*}{ No } & Kategori & \multicolumn{2}{c}{ Jumlah } \\
& & $\mathrm{N}$ & $\%$ \\
\hline 1 & Kurang Baik & 13 & 38,2 \\
2 & Baik & 21 & 61,8 \\
& Total & 34 & 100,00 \\
\hline
\end{tabular}

Dari 34 orang yang menjadi responden, yang mendapatkan dukungan keluarga baik sebanyak 21 responden (61,8\%), dan yang mendapatkan dukungan keluarga kurang baik sebanyak 13 responden $(38,2 \%)$.

Penelitian ini sesuai dengan penelitian Rizki (2015) tentang faktor-faktor yang mempengaryhi tingkat depresi pasien kanker yang di rawat di RSUD Arifin Achmad Provinsi Riau, menunjukkan bahwa responden yang memiliki dukungan keluarga yang tinggi sebanyak 33 responden $(55 \%)$, sedangkan responden yang memiliki dukungan memiliki pasangan hidup sebanyak 63 responden $(90 \%)$.

Menurut Widiyono (2017) menjelaskan bahwa status perkawinan berhubungan dengan kejadian depresi pada pasien kanker. Kejadian depresi pada pasien kanker yang tidak memiliki pasangan hidup, baik karena belum menikah, bercerai, atau pasangannya meninggal dunia, memiliki prevalensi dua kali lebih besar dibandingkan yang memiliki pasangan.

\section{Gambaran Kejadian Depresi Responden Kanker Payudara}

\begin{tabular}{cccc}
\hline \multirow{2}{*}{ No } & Kategori & \multicolumn{2}{c}{ Jumlah } \\
\cline { 3 - 4 } & & $\mathrm{nn}$ & \multicolumn{1}{c}{$\%$} \\
\hline & & & 82,4 \\
& & 228 & 14,7 \\
& & 55 & 2,9
\end{tabular}




\begin{tabular}{|c|c|c|c|c|c|c|c|}
\hline \multirow{4}{*}{\multicolumn{2}{|c|}{$\begin{array}{c}\text { No Dukungan } \\
\text { Keluar } \\
\text { ga }\end{array}$}} & \multicolumn{3}{|c|}{ Kondisi Depresi } & \multicolumn{2}{|c|}{ Jumlah } & \multirow{4}{*}{$\begin{array}{c}\text { Nilai } \\
\rho\end{array}$} \\
\hline & & \multicolumn{3}{|c|}{ Tidak DepresiDepresi } & \multirow[t]{3}{*}{$\mathrm{n}$} & \multirow[t]{3}{*}{$\%$} & \\
\hline & & Depr & ringan & sedan & & & \\
\hline & & si & & $g$ & & & \\
\hline 1 & $\begin{array}{c}\text { Kurang } \\
\text { Baik }\end{array}$ & 12 & 1 & 0 & 13 & 38,00 & \\
\hline \multirow[t]{2}{*}{2} & Baik & 16 & 4 & 1 & 21 & 62,00 & \\
\hline & Total & 28 & 5 & 1 & 34 & 100,00 & \\
\hline
\end{tabular}

Dari 34 orang yang menjadi responden, yang tidak mengalami depresi sebanyak 28 responden $(82,4 \%)$, yang mengalami depresiringan sebanyak 5 responden $(14,7 \%)$, dan yang mengalami depresi sedang sebanyak 1 orang responden $(2,9)$.

Penelitian ini sesuai dengan penelitian Riski (2015) tentang faktor-faktor yang mempengaruhi tingkat depresi pasien kanker yang dirawat di RSUD Arifin Achmad Provinsi Riau, menunjukkan bahwa responden yang mengalami depresi sedang sebanyak 23 responden (38,3\%), Responden yang mengalami depresi ringan sebanyak 20 responden $(33,3 \%)$, dan yang mengalami depresi berat sebanyak 17 responden $(28,3 \%)$.

Menurut Kaplan (2010) dalam Riski (2015) menjelaskan bahwa depresi dapat dipengaruhi oleh beberapa hal antara lainfaktor psikososial, faktor biologi, kognitif dan streesor lingkungan. Setiap individu dapat mengalami depresi sesuai kondisi dan lingkungan ataupun masalah yang dihadapi seperti saat kondisi sakit dengan diagnose medis dan dirawat inap di rumah sakit.

\section{B. Analisa Bivariat \\ 1. Hubungan Dukungan Keluarga dengan Kejadian}

\begin{tabular}{llr}
\multicolumn{2}{r}{34} & \multicolumn{1}{c}{100,00} \\
\hline $\begin{array}{l}\text { Depresi } \\
\text { Payudara }\end{array}$ & Pasien & Kanker
\end{tabular}

Dari 34 orang yang menjadi responden, 13 responden (38\%) memiliki dukungan keluarga kurang baik. Dari 21 orang yang mendapat dukungan keluarga baik, sebagian besar tidak mengalami depresi yaitu sebanyak 16 orang $(76,2 \%)$, yang mengalami depresi ringan 4orang (19\%) dan depresi sedang 1 orang $(4,8 \%)$. Dari 13 orang responden dengan dukungan keluarga kurang baik, 12 orang $(92,3 \%)$ tidak mengalami depresi, dan 1 orang mengalami depresi (7,7\%). Dan untuk kondisi depresi yang berat tidak ada hasil atau tidak adanya responden yang mengalami kondisi depresi berat. Sedangkan dapat disimpulkan, bahwa responden dengan dukungan keluarga yang baik justru lebih banyak yang mengalami depresi dibandingkan dengan responden dengan dukungan keluarga yang kurang baik.

Hasil penelitian ini sejalan dengan penelitian yang dilakukan Riski (2015) tentang faktor-faktor yang mempengaruhi tingkat depresi pada pasien kanker yang dirawat di 
RSUD Arifin Achmad Provinsi Riau yang menjelaskan bahwa ada hubungan antara dukungan keluarga dengan tingkat depresi, dengan pvalue 0,002 yang berarti $p$ value < 0,05 , dan penelitian yang dilakukan Suharmilah (2013) tentang faktorfaktor yang berhubungan dengan tingkat depresi pada pasien kanker payudara yang sudah mendapatkan terapi di RS Margono Soekarjo Purwokerto yang menjelaskan bahwa tidak adanya hubungan yang bermakna antara dukungan keluarga dengan tingkat depresi, dengan $p$ value 0,289 yang berarti $p$ value > 0,05 .

Menurut Ali (2009) dalam Riski (2015) menjelaskan bahwa dukungan keluarga berperan penting memberikan perasaan sejahtera bagi yang menerimanya. Dukungan keluarga dapat berupa komunikasi verbal dan non verbal, saran, bantuan yang nyata atau tingkah laku yang diberikan oleh orang-orang yang akrab dengan subjek didalam lingkungan sosialnya atau berupa kehadiran dalam hal-hal yang dapat memberikan keuntungan emosional atau berpengaruh pada tingkah laku penerimanya.

Hasil uji chi square (Fisher's Exact Test) menunjukkan bahwa tidak ada hubungan yang bermakna antara dukungan keluarga dengan kejadian depresi pada pasien kanker payudara di Rumah Sakit Umum Daerah Raden Mattaher Jambi dengan nilai $\rho=0,769$. Artinya dukungan keluarga yang baik tidak menghalangi ibu untuk mengalami depresi akibat kanker payudara.

Menurut peneliti, tidak adanya hubungan ini dapat dilihat dari jawaban responden saat mengisi
Instrumen Beck Depresion Inventory (BDI) antara lain tidak merasa sedih, tidak berkecil hati terhadap masa depan, tidak merasa gagal, tidak merasa bersalah, tidak merasa sedang di hukum, tidak merasa kecewa terhadap diri sendiri, tidak mempunyai pikiran bunuh diri, tidak sering menangis seperti biasanya, masih tetap bergaul dengan orang lain, tidak merasa lebih jeles fisiknya dari sebelumnya, dapat tidur dengan nyenyak, dan tidak adanya perubahan minat terhadap seks.

Selanjutnya, dari 6 responden yang mengalami depresi kemungkinan disebabkan dari beberapa faktor seperti umur responden yang rata-rata 50 tahun yang masih dalam usia reproduktif, pendidikan responden yang rata-rata SMA sederajat $(67,6 \%)$ yang tentunya sudah banyak mengetahui tentang penyakit sehingga menimbulkan kecemasan, status perkawinan responden yang rata-rata menikah dan memiliki pasangan hidup $\quad(97 \%) \quad$ sehingga menimbulkanrasa tidak berguna terhadap pasangan, pekerjaan responden yang rata-rata IRT $(85,3 \%)$ yang sering mengurus anak dan suami sehingga menimbulkan rasa cemas jika mengalami kanker payudara.

\section{SIMPULAN}

1. Karakteristik responden rata rata berumur 50 tahun, berpendidkan SMA $(67,6 \%)$, pekerjaan IRT $(85,3 \%)$ dan menikah $(97 \%)$

2. Lebih dari setengah $(61,8 \%)$ responden memiliki dukungan keluarga baik. 
3. Sebagian besar $(82,4 \%)$ responden tidak mengalami depresi.

4. Tidak ada hubungan bermakna antara dukungan keluarga dengan kejadian depresi pada pasien kanker payudara dengan nilai $p=$ $0,769(>0,05)$.

\section{SARAN}

1. Bagi Dinas Kesehatan Provinsi Jambi diharapkan dapat menjadi sumber informasi untuk lebih meningkatkan promosi kesehatan tentang kanker payudara,.

2. Bagi RSUD Raden Mattaher Jambi,agar dapat meningkatkan pelayanan dan dukungan kepada pasien-pasien kanker payudara sehingga status kesehatan pasien dapat ditingkatkan.

3. Bagi Institusi Pendidikan Kesehatan dapat menjadi bahan referensi pustaka, serta menjadi sarana informasi untuk para mahasiswa.

4. Bagi peneliti lain dapat melakukan penelitian lanjutan dengan variabel dan metode yang berbeda seperti pemilihan metode kualitatif.

\section{DAFTAR PUSTAKA}

1. Afiyanti \& Pratiwi. 2016. Seksualitas dan Kesehatan Reproduksi Perempuan. Jakarta: Rajagrafindo Persada

2. Andrews, G. 2010. Buku Ajar Kesehatan Reproduksi Wanita. Edisi ke - 2. Jakarta : EGC

3. Baradero, dayrit, siswadi. 2007. Seri Asuhan Keperawatan Klien
Gangguan Sistem Reproduksi dan Seksualitas. Jakarta : EGC

4. Dahlan, S. 2014. Statistik Untuk Kedokteran dan Kesehatan: Deskriftif, Bivariat, dan Multivariat. Jakarta. Epidemiologi Indonesia

5. Dewi Puspita. 2014. Gambaran Dukungan Keluarga Pada Pasien Kanker Yang Menjalani Terapi Di RSUD Panembahan Senopati Bantul. Jurnal Keperawatan Universitas Muhammadiyah Volume 2 Nomor 2. Oktober 2014

6. Dinas Kesehatan Provinsi Jambi. 2017. Data Pasien Kanker Provinsi Jambi. Provinsi Jambi

7. Friedman, M. 2010. Buku Ajar Keperawatan Keluarga : Riset, Teori, dan Praktek. Edisi ke - 5.Jakarta : EGC

8. Hawari, D. 2016. Manajemen Stress Cemas dan Depresi.Jakarta : Badan Penerbit FKUI

9. Husni, Siti, Desi. 2012. Hubungan Dukungan Keluarga Dengan Kualitas Hidup Pasien Kanker Payudara Di InstalasiRawat Inap RSUD Dr. Mohammad Hoesin Palembang tahun 2012 . Jurnal Keperawatan Sriwijaya Volume 2 Nomor 2. Juli 2015

10. Kemenkes RI. 2015. Situasi Penyakit Kanker. Jakarta : Kementerian Kesehatan Republik Indonesia

11. $2014 . \quad$ Riset Kesehatan Dasar 
(Riskesdas).Jakarta : Badan Litbang Kemenkes RI

12. Lyndon,S. 2013. Pengantar Kebutuhan Dasar Manusia. Jakarta : Binarupa Aksara

13. Mahwita, dkk.2012. Hubungan Dukungan

Keluarga Terhadap Motivasi Pasien Kanker Payudara Dalam Menjalani Kemoterapi Di Ruang Cendrawasih I RSUD Arifin Achmad Provinsi Riau.Jurnal penelitian Ners Indonesia Volume 2 Nomor 2 Maret 2012.

14. Mulyani \&Nuryani.2013. Kanker Payudara dan PMS Pada Kehamilan.Yogyakarta : Nusa Medika

15. Notoatmodjo, S. 2012. Metodologi Penelitian Kesehatan.Jakarta : Rineka Cipta

16. Nurpeni \& Ratih. 2012. Hubungan Dukungan

Keluarga Dengan Tingkat Kecemasan Pada pasien Kanker Pasien Kanker Payudara Di Ruang Asoka III RSUP Sanglah Denpasar. Jurnal Keperawatan Universitas Udayana Volume 2 Nomor 2. Nopember 2012

17. Nursalam. 2008. Konsep dan Penerapan Metodologi Penelitian Ilmu Keperawatan. Jakarta : Salemba Medika

18. 2011. Konsep dan Penerapan Metodologi Penelitian Ilmu Keperawatan. Jakarta : Salemba Medika

19. Olfah, Mendri, Badi'ah. 2013. Kanker Payudara Dan Sadari.Yogyakarta : Nusa Medika
20. Perry \& Potter. 2010. Fundamental Keperawatan. Jakarta: Salemba Medika

21. Prawirohardjo S. 2009. Ilmu Kandungan. Jakarta : Bina Pustaka

22. Priscilla, Karen, Gerene. 2017. Keperawatan Medikal Bedah Gangguan Reproduksi. Jakarta : EGC

23. Reeder, Martin, Koniak. 2011. Keperawatan Maternitas. Kesehtan wanita, bayi, \& keluarga. Edisi ke 18. Jakarta : EGC

24. Ria, R. 2016. Kenali Kanker sejak Dini.Yogyakarta : Rapha Publishing

25. Riski Suwistiyanisa. 2015. Faktor-faktor yang mempengaruhi tingkat depresi pada pasien kanker yang dirawat di RSUD Arifin Achmad Provinsi Riau. Jurnal Keperawatan Universitas Riau. Volume 2 Nomor 2. Oktober 2015

26. Rosa. 2012. Perilaku Asertif, Harga diri dan Kecenderungan

Depresi.Jurnal penelitian Psikologi Indonesia Volume 1 Nomor 2 September 2012.

27. Rekam Medik RSUD Raden Mattaher Jambi.2017. Jumlah Penderita Kanker Payudara yang Menjalani Kemoterapi.Jambi

28. Suharmilah. 2013. Faktorfactor yang berhubungan dengan tingkat depresi pada pasien kanker payudara yang sidah mendapatkan terapi di Rumah Sakit Margono Soekarjo Purwokerto. Jurnal Penelitian Mandala Of Health 
Volume 6 Nomor 1 Januari 2013.

29. Widiyono. 2017. Tingkat Depresi Pada Pasien Kanker di RSUP Dr. Sardjito,
Yogyakarta dan RSUP Prof.

Dr. Margono, Purwokerto.

Jurnal Of Cancer Indonesia Volume 11 Nomor 4. Oktober-Desember 2017. 